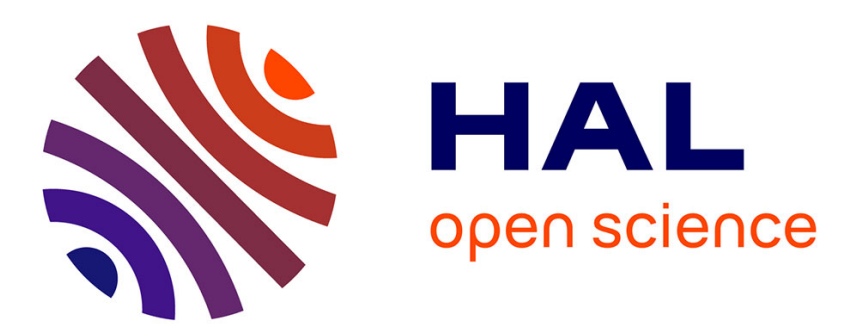

\title{
"Rabbinic Universalism Reconsidered: The Roman Context of some Rabbinic Traditions Pertaining to the Revelation of the Torah in Different Languages"
}

Katell Berthelot

\section{- To cite this version:}

Katell Berthelot. "Rabbinic Universalism Reconsidered: The Roman Context of some Rabbinic Traditions Pertaining to the Revelation of the Torah in Different Languages". Jewish Quarterly Review, 2018, 108 (4), pp.393-421. hal-02519817

\section{HAL Id: hal-02519817 \\ https://hal.science/hal-02519817}

Submitted on 17 Dec 2021

HAL is a multi-disciplinary open access archive for the deposit and dissemination of scientific research documents, whether they are published or not. The documents may come from teaching and research institutions in France or abroad, or from public or private research centers.
L'archive ouverte pluridisciplinaire HAL, est destinée au dépôt et à la diffusion de documents scientifiques de niveau recherche, publiés ou non, émanant des établissements d'enseignement et de recherche français ou étrangers, des laboratoires publics ou privés. 


\title{
Rabbinic Universalism Reconsidered: The Roman Context of some Rabbinic Traditions Pertaining to the Revelation of the Torah in Different Languages
}

\author{
KATELL BERTHELOT
}

\section{INTRODUCTION}

A Famous Passage in Sifre Deuteronomy states that God did not intend to reveal the Torah to Israel alone but also to all the nations (umot). ${ }^{1}$ The midrash does not, however, specify the language in which the Torah was meant to be communicated to them. In the end, God's plan failed, and the Torah was not revealed to the nations. According to another rabbinic tradition going back to the tannaitic period, the laws of the Torah were translated into seventy languages - all the languages of humankind - after Israel had arrived in the Promised Land. The idea that the divine laws were communicated to humankind in different languages fits in well with Philo's understanding of the translation of the Torah into Greek as part of making the divine law available not only to the "barbarian" half of humankind but also to the Greek-speaking half. ${ }^{2}$ At first

This research was funded by the European Research Council (ERC) under the European Union's Seventh Framework Program (FP/2007-2013)/ERC Grant Agreement no. 614 424. It was conducted within the framework of the ERC project Judaism and Rome, under the auspices of the Centre National de la Recherche Scientifique (CNRS) and Aix-Marseille University, UMR 7297 TDMAM (Aix-en-Provence, France). I wish to thank the participants of the workshop Languages of Empire, organized by Oded Irshai and Jonathan Price at Zikhron Yaakov in November 2016, for their comments and feedback, and Steven Fraade in particular for sharing with me his forthcoming essay "The Torah Inscribed/Transcribed in Seventy Languages" and discussing a previous version of my essay with me. I also thank the anonymous reviewers of $J Q R$ for their helpful suggestions and comments.

1. SifreDt $\$ 343$ (ed. Finkelstein, 396).

2. See De Vita Mosio 2.27, a passage in which Philo refers to the famous story of the translation of the Septuagint, known from the Letter of Aristeas. 
glance, a universalist perspective seems to be at work in the rabbinic traditions as well. However, the meaning of the rabbinic tradition greatly differs from Philo's perspective, as we will see.

In this essay, focusing on rabbinic evidence from Erets Yisra'el, I will examine a group of texts pertaining to the translation of the laws of the Torah into seventy languages. These texts are based on biblical traditions regarding the transcription of the Torah on stones after Israel's entrance into the Promised Land. Most of these texts interpret the biblical traditions as referring to the communication of at least part of the laws of the Torah to humankind as a whole and have thus been discussed in the context of a reflection on the universalist dimension of rabbinic thought and the existence of a universalist conception of the law in early rabbinic literature. ${ }^{3}$ Whereas the universalist dimension of most of the rabbinic texts pertaining to the translation of the laws of the Torah into seventy languages is in itself indisputable, my goal is to analyze the significance of this tradition in greater depth, by assessing the impact of the Roman context in which the rabbis lived on this literary tradition, bringing additional rabbinic texts and Roman literary, epigraphic, and legal evidence into the conversation. My argument is that, to a great extent, these rabbinic texts interpret the biblical traditions in light of Roman norms concerning the communication of laws and edicts in the empire, a point already briefly hinted at by Saul Lieberman in his book Hellenism in Jewish Palestine. ${ }^{4}$ Moreover, these rabbinic texts reproduce or echo Roman legal reasoning. As a consequence, the universalist perspective at work in these texts can be considered both a mimicry of Roman universalism and an expression of opposition to the Roman model.

First, however, we need to look at each text separately and understand the exegetical dynamics and the inner logic at work in each of them.

\section{THE TRANSLATION OF THE TORAH \\ INTO SEVENTY LANGUAGES ${ }^{5}$}

The rabbinic traditions pertaining to the translation of the Torah into seventy languages are connected to specific biblical passages that require

3. See in particular Marc Hirshman, Torab for the Entire World (Hebrew; Tel Aviv, 1999), 105-13; Hirshman, "Rabbinic Universalism in the Second and Third Centuries," Harvard Theological Review 93 (2000): 101-15.

4. Lieberman, Hellenism in Jewish Palestine: Studies in the Literary Transmission, Beliefs, and Manners of Palestine in the I Century B.C.E.-IV Century C.E. (New York, 1950), 200-202.

5. A detailed and very clear presentation of the issues at stake in both the biblical and the rabbinic passages related to this tradition can be found in Steven 
exegetical clarification, Dt 27.2-8, Josh 8.30-35, and Josh 4.1-10. Most crucial in this respect is Dt 27.2-8, which states:

2 And on the day you pass over the Jordan to the land which the Lord your God gives you, you shall set up large stones, and plaster them with plaster [ve-sadeta otam basid] 3 and you shall write upon them all the words of this law [ve-kbatavta 'aleben et-kol-divre ba-torab ba-zo't], when you pass over to enter the land which the Lord your God gives you, a land flowing with milk and honey, as the Lord, the God of your fathers, has promised you. 4 And when you have passed over the Jordan, you shall set up these stones, concerning which I command you this day, on Mount Ebal, and you shall plaster them with plaster. 5 And there you shall build an altar to the Lord your God, an altar of stones: you shall lift up no iron tool upon them. 6 You shall build an altar to the Lord your God of unhewn stones; and you shall offer burnt offerings on it to the Lord your God; 7 and you shall sacrifice peace offerings, and shall eat there; and you shall rejoice before the Lord your God. 8 And you shall write upon the stones all the words of this law [ve-khatavta 'al-ba-'avanim et-kol-divre ha-torab ba-zo't] very plainly [ba'er betev]. (NRSV) ${ }^{6}$

This passage is full of ambiguities, even if we leave aside the repetition between verses 2 and 4 . These two verses apparently prescribe copying the Torah on large stones that will first have been erected and plastered, whereas vv. 5-7 command the Israelites to build an altar of unhewn stones on Mount Ebal. As for verse 8, it can be read as signifying that the words of the Torah are to be written on the altar. Verse 8 does not make clear on which of these various "stones" the words of the law should be written. From a syntactic point of view, it makes sense to assume that the "stones" in v. 8 are the same as those in v. 7, namely, the stones of the altar; but from a logical point of view it seems more probable that v. 8 repeats the command found in vv. 2-4, as the unhewn stones of the altar hardly seem fit to receive a written inscription.

This passage is echoed in Josh 8.30-35, which reports how Joshua implemented what had been prescribed by Moses. There are, however, important differences between the two passages, because the account in Joshua 8 does not mention the stones taken from the midst of the Jordan

Fraade, "The Torah Inscribed/Transcribed in Seventy Languages," in Hebrew between Jews and Christians, ed. D. S. Kokin (Berlin, forthcoming).

6. Translations of biblical texts are from the NRSV, unless stated otherwise. 
River-which, according to Joshua 4 , were set up at Gilgal as a memorial - or the plaster. The account in Joshua 8 merely states that Joshua built an altar of unhewn stones on Mount Ebal (vv. 30-31) and adds: "And there, in the presence of the Israelites, Joshua wrote on the stones a copy of the law of Moses, which he had written" (v. 32), before reporting the reading of the law and the recitation of the blessings and curses, as prescribed in Deuteronomy 27-28. The account in Joshua 8 thus seems to imply that the law was written on the stones of the altar.

\section{I.1 Mishnab Sotah 7.5}

In $\mathrm{mSot} 7.5$, the passage from Deuteronomy 27 is interpreted as follows:

And afterward they brought the stones and built the altar and plastered them [the stones] with plaster and wrote upon them all the words of the law [et-kol-divre ba-torab ba-zo't] [in] seventy languages, as it is written, very plainly [ba'er hetev, Dt 27.8]. And they took the stones and came and spent the night in their own place [ve-linu bi-mekoman]. ${ }^{7}$

The Mishnah interprets the expression "very plainly" (ba'er hetev) in Dt 27.8 to mean that the law was written upon the stones in seventy languages, the number seventy being used to represent all the languages. According to this tradition, the Torah was not communicated to the nations at Sinai (as God intended in SifreDeut) but after the Israelites had arrived in the Promised Land, in Canaan.

There is widespread scholarly consensus interpreting mSot 7.5 as referring to the transcription of the Torah in the languages of the nations. However, both Willem Smelik and Steven Fraade have challenged this interpretation. In connection with the other passage in the Mishnah that mentions seventy languages (mShek 5.1), Fraade understands the text to reflect a philosophy of language that requires the translation of the Torah into seventy languages in order for the Torah to reveal the whole depth of its meaning to Israel. According to this interpretation, Israel, and not the nations, is the recipient of the translation. Fraade thus warns against attributing to the Mishnah the same meaning expressed in the Tosefta and in later sources. ${ }^{8}$ Whereas I fully agree with Fraade that in

7. MS Kaufmann, consulted on the website of the Academy of the Hebrew Language (Ma'agarim). The translation is mine.

8. See Steven Fraade, "Before and after Babel: Linguistic Exceptionalism and Pluralism in Early Rabbinic Literature and Jewish Antiquity," Diné Iorael 28 (2011): 31 *-68*, esp. 54*-55\%; Fraade, “The Torah Inscribed." See also Willem Smelik, Rabbis, Language and Translation in Late Antiquity (Cambridge, 2013), 2930, who writes: "The Mishnah does not indicate that these translations were aimed at the nations - not even that they were aimed at Israel's enlightenment." 
this particular case (as in numerous others), the nature of the relationship between the Mishnah and the Tosefta is difficult to establish, and the two texts are better studied as two different ways of understanding a shared tradition, I nevertheless consider it possible and even likely that the translation of the Torah into seventy languages in the Mishnah is aimed at communicating God's law to the nations, even if this point remains implicit (see below). Ultimately, both readings are possible. ${ }^{9}$

Beyond the interpretation of ba'er betev, two aspects of this mishnaic passage must be emphasized: first, whereas Dt 27 distinguishes between the stones that are to be plastered on the one hand, and the unhewn stones of the altar on the other, this mishnah refers to both in one short sentence: "And afterward they brought the stones and built the altar and plastered them with plaster and wrote upon them all the words of the law." As a consequence, it looks as if the stones on which the Torah was written in seventy languages were the stones of the altar, as Dt 27.8 may actually be understood to mean, and as we read in Josh 8.32 (the Mishnah adding that the stones were plastered).

Second, the sentence "And they took the stones and came and spent the night in their own place [ve-linu bi-mekoman]" implies that the Mishnah also connects Dt 27.8 with Josh 4.3 (or 4.8), which states, "Command them: take twelve stones from here out of the midst of the Jordan, from the very place where the priests' feet stood, and carry them over with you, and lay them down in the place where you lodge [ba-malon asher talinu vo] tonight" (in Josh 4.8: "and they carried them over with them to the place where they lodged [el ba-malon], and laid them down there"). In the biblical narrative, the action of taking the stones and carrying them to the place where the Israelites are supposed to lodge pertains to the stones taken from the midst of the river Jordan and precedes the episode in chapter 8 in which Joshua implements Moses's commandments as formulated in Dt 27.5-8. Moreover, according to Josh 4.24, these stones are

On the contrary, Judith Hauptman considers that "the redactor of the Mishnah reworked the Tosefta in order to make a number of points of his own," so that the mishnaic text represents a shortened version of tSot 8.6-9 (Rereading the Mishnab: A New Approach to Ancient Jewish Texts [Tübingen, 2005], 109-124, quotation at 116). Smelik rejects Hauptman's theory (Rabbis, Language and Translation, 32, n. 69). On the problem of the relationship between the Mishnah and the Tosefta more generally, see Shamma Friedman, "The Primacy of Tosefta to Mishnah in Synoptic Parallels," in Introducing Tosefta: Textual, Intratextual and Intertextual Studies, ed. H. Fox and T. Meacham (Hoboken, N.J., 1999), 99-121.

9. Moreover, as Fraade pointed out to me in a private communication, the two interpretations of $\mathrm{mSot} 7.5$ (seventy languages meant to reveal the full meaning of the text and seventy languages for the nations) need not be mutually exclusive. 
meant to be a testimony of God's power to the nations of the world. According to the tradition found in the Mishnah, Dt 27.2 ("And on the day you pass over the Jordan to the land which the Lord your God gives you, you shall set up large stones, and plaster them with plaster") referred to the stones mentioned in Josh 4. Therefore an alternative interpretation of the mishnaic passage emerges, as a conflation of Dt 27 and Josh 4, in which "they brought the stones" refers to the stones taken from the Jordan river (first part of Dt 27.2, first part of Josh 4.3 and 8); "and built the altar" refers to Dt 27.5-6; "and plastered them with plaster and wrote upon them all the words of the law" refers to Dt 27.2 and 8; "and they took the stones and came and spent the night in their own place" refers to the final part of Josh 4.3 and 8. According to this interpretation, the law was not written on the stones of the altar but on the stones taken from the Jordan River, which according to the book of Joshua were to be erected as a memorial for both Israel and the nations. The statement that the law was written in seventy languages - the languages of the nations - then becomes all the more understandable and can be seen as an exegetical development based on Josh 4.24.

The reference to Josh 4 and the place where Israel is going to lodge, the malon, has further implications in the context of the discussion in the Jerusalem Talmud. Before we analyze the talmudic evidence, however, we must first look at other tannaitic traditions, found in the Tosefta and in Mekhilta Deuteronomy.

\section{I.2 Tosefta Sotab 8.6-7}

R. Yehudah says: They wrote it [the Torah] on the stones of [the] altar. They told him: How did the nations of the world learn [the laws of] the Torah? He told them: This teaches that God inspired [lit.: gave in] the heart of every nation and every kingdom, and they sent their scribes [notarim, from notarius in Latin], and they transcribed [vebisi ${ }^{10}{ }^{10}$ the text that stood on the back of the stones in seventy languages. On that very hour, the decree of the judgement of the nations of the world was sealed [and they were doomed] to the pit of destruction.

R. Shimeon says: They wrote [the laws of the Torah] on the plaster. How? They panelled it and plastered it with plaster, and they wrote on it all the words of the Torah in seventy languages. And at the bottom

10. Lit.: "lifted." See Marcus Jastrow, A Dictionary of the Targum, the Talmud Babli and Jerushalmi, and the Midrashic Literature (New York, 1926), 938, who quotes this passage. See also Fraade, "The Torah Inscribed," nn. 27 and 28. 
they wrote: That they may not teach them [MT: you] [to do according to all their abominable practices which they have done in the service of their gods] [Dt 20.18]. If you repent from them, ${ }^{11}$ we shall receive [or: accept] you. ${ }^{12}$

This passage is part of an aggadic discussion concerning Israel's entrance into the Promised Land, especially as narrated in Josh 4.1-18. The section under study comes immediately after the statement that there were three types of stones: those set up by Moses on the riverbank of the Jordan, in the plains of Moab; those set up by Joshua in the middle of the Jordan, in the place where the feet of the priests stood (Josh 4.9); and those that the Israelites took and carried with them (Josh 4.8). Then R. Yehudah, a prominent student of R. Akiva, and by far the most often named rabbi in the Mishnah and the halakhic midrashim associated with the school of R. Akiva, ${ }^{13}$ makes the statement that they wrote (the Torah) on the stones of the altar, thus introducing a fourth category of stones, those of the altar. To this statement, which as we saw previously is a possible interpretation of Dt 27.5-8 and Josh 8.32, R. Shimeon responds that they wrote on the plaster. He could be referring either to the plastered stêlai (or stelae) mentioned in Dt 27.2-4, or to the plastered stones of the altar, in which case we should probably postulate that the redactor knew of the tradition in mSot 7.5 , because none of the biblical texts mentions a plastered altar, and therefore this information would come rather from a straightforward reading of the Mishnah: "(they) built the altar and plastered them [the stones] with plaster and wrote upon them all the words of the law [in] seventy languages."

The parallel passage in the Babylonian Talmud (bSot 35b-36a) features a similar discussion between R. Yehudah and R. Shimeon and clearly revolves around the question: Was the Torah written directly on the stones (which would later be covered with plaster), or was it written on the plaster laid on the stones? While Saul Lieberman has shown that such a discussion was meaningful in the Babylonian cultural context, ${ }^{14}$

11. With a small correction (bahem instead of bakhem).

12. My translation, based on MS Vienna, consulted on the website of the Academy of the Hebrew Language (Ma'agarim); the text differs only slightly from the edition of Saul Lieberman (Tosefta ki-fshutah: A Comprehensive Commentary on the Tosefta [Hebrew; New York, 1972], Nashim 2:205).

13. See Kahana, "The Halakhic Midrashim," in The Literature of the Sages, Second Part: Midrash and Targum, Liturgy, Poetry, Mysticism, Contracts, Inscriptions, Ancient Science and the Languages of Rabbinic Literature, ed. S. Safrai et al. (Assen; Minneapolis, Minn., 2006), 30-33.

14. See Lieberman, ed., Tosefta ki-fohutah, Nashim 3:700. 
this is not the context in which the Tosefta was redacted. Moreover, because of the preceding passage in the Tosefta, which mentions different kinds of stones, it is probable that R. Shimeon is in fact arguing that the Torah was written on the erected and plastered stelae rather than on the plastered stones of the altar. ${ }^{15}$

Whatever the exact nature of their disagreement concerning the stones, both R. Yehudah and R. Shimeon state that the Torah was made known to the nations in their own languages, but neither refers to the expression ba'er hetev found in Dt 27.8, as was the case in the Mishnah. The discussion between them implies that the tradition from the Mishnah, or an oral tradition concerning the revelation of the Torah in seventy languages, was already known to the redactors of the Tosefta, who did not need to ground it in a particular biblical verse.

Both R. Yehudah and R. Shimeon state that the Torah was made known to the nations in their own languages, but their teachings differ. First, it seems that R. Yehudah means that the Torah was written on the stones in Hebrew alone, whereas R. Shimeon explicitly states that the Torah was written on the stones in seventy languages (apparently by the Israelites themselves). The problem raised by R. Yehudah, which prompts his question "How did the nations of the world learn [the laws of] the Torah?" could be connected either to the fact that the stones of the altar were about to be plastered, and as a consequence the law would soon be covered by the plaster, or to the fact that the altar was to be dismantled - as a straightforward reading of the Mishnah would imply - or to the fact that the law was written down in Hebrew alone. Whatever the case, the solution attributed to R. Yehudah is that God inspired the nations to send notarim or scribes (on this word, see the second part of this essay), who translated or transcribed the words of the law into their own languages and brought the divine revelation back to their peoples. ${ }^{16}$ There is thus no doubt that it was God's design to communicate the law to the nations. However, the underlying idea is not primarily that of the universality of revelation but the fact that individuals and nations cannot be punished justly if the law has not been communicated to them first, since one who is ignorant cannot be judged and punished

15. Saul Lieberman favors this interpretation in light of the parallel in MekhiltaDt. See Lieberman, ed., Tosefta ki-fobutah, Nashim 3:700-701, and $\$ 1.3$ below.

16. The meaning of ve-bisi'u et ba-ktav is not completely clear, as we could have expected tirgemu, "(they) translated," instead of bisi'u. However, the interpretation according to which the scribes merely copied a text that was already written in their own language is not satisfying in the framework of the discussion with R. Shimeon. See Fraade, "The Torah Inscribed," at nn. 27 and 28. 
for a crime he is not aware of having committed. ${ }^{17}$ In the opinion associated with $\mathrm{R}$. Yehudah, the fact that the law was made known to the nations in their own languages implies that from that moment onward, they could legitimately be judged and doomed to destruction (their disobedience to the divine laws being obvious in his perspective).${ }^{18}$ Here the relationship to the nations seems wholly negative, and even, as Fraade argues, cynical. ${ }^{19}$

R. Shimeon's perspective differs from that of R. Yehudah. First, according to him, the nations had easy access to the Torah because it was already written in seventy languages on the plastered stones, and if we are correct in understanding that for him the stones were the stelai, it means that the Torah was published permanently on the stones. Interestingly enough, one biblical verse is singled out: "And at the bottom they wrote: That they may not teach them [MT: you] [to do according to all their abominable practices which they have done in the service of their gods]" (Dt 20.18). In the context of a discussion on the traditions pertaining to the crossing of the Jordan and the conquest of the land, the choice of this biblical verse, which pertains specifically to the Canaanites and serves to justify their extermination by herem, can hardly be casual. Ultimately, R. Shimeon's teaching is aimed at the nations in general, but let us not overlook the fact that it concerns the Canaanites in the first place. Contrary to the plain meaning of Dt 20, the Tosefta attributes to R. Shimeon the bold idea that the laws of the Torah were made known to the Canaanites, that they were warned of their future fate and given the possibility of repenting and being received among the Israelites. This teaching therefore represents a much more lenient and inclusive attitude toward the Canaanites - and by extension all gentiles - than Deuteronomy or other biblical traditions. It also represents a much more positive and inclusive attitude than the one attributed to R. Yehudah. The fact remains, however, that even according to $\mathrm{R}$. Shimeon the Canaanites did not repent at the time of the conquest and were doomed to destruction, like the nations in the scenario associated with R. Yehudah. ${ }^{20}$ Nevertheless, it is possible

17. See also Hirshman, Torah for the Entire World, 106.

18. Cf. Smelik, Rabbis, Language and Translation in Late Antiquity, 31; and Fraade, "The Torah Inscribed": "The purpose of making the Torah available to the nations in their own languages was hardly altruistic, but to guarantee their divine punishment for transgressing its laws by denying them the claim that they were innocent by virtue of not having had access to (that is, comprehension of) the Torah in their native tongues."

19. Fraade, "The Torah Inscribed."

20. In the parallel discussion found in MekhiltaDt on Dt 27.8, the other part of the laws of war is quoted, which does pertain to the cities outside the land of 
that in the perspective attributed to R. Shimeon, beyond the case of the Canaanites, the door of repentance remained open for other peoples.

\section{I.3 Mekbilta Deuteronomy on Dt 27.8}

A similar discussion in yet another tannaitic text pertains to the issue of the Torah written on the stones after Israel's entrance into Canaan. Mekhilta Deuteronomy is a halakhic midrash usually associated with the school of R. Ishmael, which is preserved only in fragments from the Cairo Genizah or in late compilations which have added other elements to the original midrash, making it difficult to recover. Here I rely on a fragment from the Genizah and follow the edition of Menahem Kahana (in this excerpt, the square brackets correspond to the parts of the text that are reconstructed by the editor, Kahana, and thus should not be confused with the parentheses I have inserted to facilitate the reading or to provide additional information): ${ }^{21}$

$5 \ldots$ On that very day Israel crossed (the Jordan), and they took the stones and carried them away 6 and erected them and they wrote on [the stones] all the words of the Torah [in the holy language (i.e., Hebrew)]. 7 R. Ishmael says: they wrote (them) in seventy languages [as it is said: very plainly (Dt 27.8)]. Rabbi 8 Shimeon ben Yohai says: They did not write (anything) upon the[m b]ut[ a copy of] the Law (Torah) of Moses, as it is said: 9 He wrote there, upon the stones, a copy of the law of Moses (etc.) (Josh 8.32). vacat R. Yose 10 ben Yosi ${ }^{22}$ says in the name of R. Eleazar ben Shimeon: They did not write upon them (anything) but what the nations 11 of the world want; for example: When you draw near to a city to fight against it, offer terms of peace to it. 12 If its answer to you is peace (and it opens to you, then all the people who are found in it shall do forced labor for you and shall serve you) (Dt 20.10-11); When you besiege a city for a long time, (making war against it in order to take it, you shall not destroy its trees etc.) (Dt 20.19). (It is) on [the stones] 13 [of the alta] $\mathrm{r}$ that they wrote them (the words of Torah), according to R. Yehudah. R. Shimeon said: They wrote them upon the stones

Israel (Dt 20:10-11, and also 19). The conclusion in the end is the same, however: the nations are judged and condemned for having rejected the laws of God.

21. M. Kahana, The Genizab Fragments of the Halakbic Midrashim, Part 1 (Jerusalem, 2005), 345, no. 10, ll. 5-17. See also Lieberman, ed., Tosefta ki-fobutah, Nashim 3:700-701; Marc Hirshman, Torab for the Entire World, 109-10. The English translation is mine.

22. Lieberman notes that this is the only reference to a tannaitic sage named in such a way (Tosefta ki-fobutab, Nashim 3:700, n. 17). 
(which were set up on Mount Ebal). [R. ... said:] 14 The words of R. Shimeon who said "[They wrote them] upon the stones" look (more convincing) 15 [-as it is said: Upon] the stones (Josh 8.32) - than the words of R. Yehudah who said "They wrote them upon the altar." They asked: 16 They wrote them [upon] the altar? How (could) the nations of the world see ${ }^{23}$ their judgement happen? 17 [And at the bottom they wrote] on them: "Everyone who wants to make peace (lit.: receive the right [hand]), let him come and make peace." And they hid them (the stones) on that very day.

This aggadic section shares several features with the passages from the Mishnah and the Tosefta examined previously. It echoes the anonymous tradition found in the Mishnah, according to which the Torah was written on the stones in seventy languages, and connects it with R. Ishmael, not surprisingly in view of his universalistic views. ${ }^{24}$ It also reproduces the discussion between R. Yehudah and R. Shimeon found in the Tosefta but has a different version of it.

According to the anonymous opinion with which the text opens, the Torah was written on the stones that were taken from the midst of the Jordan River, carried away and erected (on Mount Ebal), in accordance with Josh 4.3 and Dt 27.2-4. The first issue discussed by the MekhiltaDt, if we follow Kahana's reconstruction of the text in line 6, is language. Then comes the issue of content, and, finally, we return to the question of whether the Torah was written on the stones of the altar or on the stones which were set up on Mount Ebal (Dt 27.4).

Concerning the issue of language, the anonymous opinion that the Torah was written on the stones in Hebrew (according to Kahana's reconstruction), which probably corresponds to the opinion of R. Yehudah in the Tosefta, is rejected by R. Ishmael, who, in agreement with the Mishnah, states that the Torah was written on the stones in seventy languages. The fact that this potentially universalistic idea is attributed to

23. Following a correction proposed by Lieberman in Tosefta ki-fshutab, Nas$\operatorname{him} 3: 701$.

24. See Hirshman, "Rabbinic Universalism"; Hirshman, Torab for the Entire World, 109-10. On the schools of R. Ishmael and R. Akiva and their different understandings of Scripture, see the important work of Azzan Yadin-Israel, in particular "Concepts of Scriptures in the Schools of Rabbi Akiva and Rabbi Ishmael," in Jewish Concepts of Scripture: A Comparative Introduction, ed. B. D. Sommer (New York, 2012), 47-63; and his two monographs, Scripture as Logos: Rabbi Isbmael and the Origins of Midrasts (Philadelphia, 2004), and Scripture and Tradition: Rabbi Akiva and the Triumph of Midrasb (Philadelphia, 2015). 
R. Ishmael makes sense in view of Hirshman's characterization of R. Ishmael's school as more universalistic than that of R. Akiva. ${ }^{25}$ Kahana has also drawn attention to the fact that, although the differences between the two schools are much less significant in the aggadic parts of the midrashim than in the halakhic parts, at least certain nonlegal portions of MekhiltaDt are characterized by a more universalistic attitude toward the non-Jews than the corresponding passages in SifreDt. ${ }^{26}$

With R. Shimeon ben Yohai we then move to the topic of the content of the law that was written on the stones. ${ }^{27}$ In the first stage of the discussion (l. 6) it was stated that "all the words of the Torah" were written on the stones. According to R. Shimeon, however, they wrote "a copy of the Law of Moses," mishne Torat Moshe (a quotation from Josh 8.32). Hirshman interprets this expression as a reference to the book of Deuteronomy alone, which is indeed a repetition or a reformulation (mishne) of the Law of Moses. After R. Shimeon's statement comes a vacat, which could indicate that the discussion enters into a new stage. However, the repetition of the same phrase or wording by R. Shimeon and R. Yose and the nature of the arguments clearly show that their statements are connected. As a matter of fact, R. Yose answers R. Shimeon, by further debating which part of the Torah was written on the stones. For R. Yose, it was not the whole of Deuteronomy that was written on the stones but merely the commandments pertaining to the wars between Israel and the nations. As Saul Lieberman remarks, "In the opinion of this Rabbi it is portions of

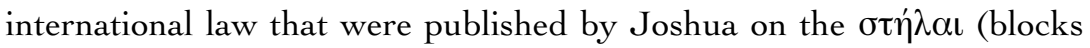
of stone) which he set up." ${ }^{28}$ The first quotation, Deuteronomy 20.10-11, refers to the rules of a war waged by Israel against cities located outside Canaan, the only ones to which peace can be offered. The second quotation, Deuteronomy 20.19, is also a general rule of war, pertaining to the trees: in contrast to human beings, trees are not enemies and should not be destroyed. We could thus conclude that Israel wrote down only the commandments pertaining to the wars against the nations that were not Canaan. The end of the text, however, shows that the midrash actually

25. Hirshman, "Rabbinic Universalism."

26. See Kahana, "The Halakhic Midrashim," 51, as well as Kahana, "Pages of the Deuteronomy Mekhilta on Ha'azinu and Wezot Ha-berakba," Tarbiz 57 (1988): 165-201, esp. 180-85, 200-201.

27. Note that in the parallel discussions in the Jerusalem Talmud (ySot 7.5 [21d]) and in the Babylonian Talmud (bSot 35b-36a), the issue of the content of the Torah written on the stones is not debated. This point is specific to Mekhilta Deuteronomy.

28. Lieberman, Hellenism in Jewish Palestine, 202. 
does not follow the literal meaning of Deuteronomy 20 but extends the offer of peace to the Canaanites as well: "Everyone who wants to make peace, let him come and make peace" (1. 17). This radical reinterpretation of Deuteronomy 20 can be found in later rabbinic texts as well, for instance in yShev 6.1 (36c), in LevR 17.5-6 (on Lev 14.34), or in DeutR 5.14 (on Dt 20.10), which all state that before the conquest of Canaan, Joshua sent prostagmata and offered peace to the Canaanites who wanted to make peace..$^{29}$ In the end, the MekhiltaDt argues that the possibility of making peace with Israel was communicated to the Canaanites, as well as to the nations in general, through the revelation of at least these crucial verses of the Torah. ${ }^{30}$ An underlying question is whether the Canaanites' fate was just or not, in other words, whether they had been warned or not. Moreover, as the question raised in line 17- "How (could) the nations of the world see their judgement happen?"-shows, the midrashic reasoning pertains not only to the Canaanites, the people whom Israel encountered after having crossed the Jordan, but also to the nations in general, which received knowledge of at least some laws of the Torah and did not behave accordingly. Finally, it must be emphasized that R. Yose's opinion, which we had not yet encountered, displays a less universalistic view of the communication of the Torah than those of R. Ishmael (who, however, does not discuss content) and R. Shimeon.

The question of the communication of the Torah to the nations also underlies the last issue discussed in this passage of the MekhiltaDt, the nature of the stones on which the Torah (or part of it) was supposed to be written. As in the Tosefta, R. Yehudah argues that the Israelites wrote

29. On these rabbinic traditions, see Wilhelm Bacher, "The Supposed Inscription upon 'Joshua the Robber,' Illustrated from Jewish Sources," JQR 3.4 o.s. (1891): 354-55; Victor Aptowitzer, "Les premiers possesseurs de Canaan, légendes apologétiques et exégétiques," Revue des Etudes Juives 82 (1926): 274-86; Hans (Yohanan) Lewy, "Ein Rechtsstreit um Boden Palästinas im Altertum," Monatoschrift für Geschichte und Wissenschaft des Judentums 77 (1933): 84-99, 172-80; Philip Alexander, "The Toponymy of the Targumim with Special Reference to the Table of the Nations and the Boundaries of the Land of Israel" (Ph.D. diss., University of Oxford, 1974), 92-105; Katell Berthelot, "The Canaanites who 'Trusted in God': An Original Interpretation of the Fate of the Canaanites in Rabbinic Literature," JJS 62.2 (2011): 233-61; Menahem Kister, "The Fate of the Canaanites and the Despoliation of the Egyptians. Polemics among Jews, Pagans, Christians, and Gnostics: Motifs and Motives," in The Gift of the Land and the Fate of the Canaanites in Jewish Thought, ed. K. Berthelot, J. David, and M. Hirshman (New York, 2014), 66-111.

30. Peace probably implied repentance from idolatry as well, at least if the Canaanites were to stay in the country. 
on the stones of the altar, while R. Shimeon apparently thinks that they wrote on the stones that were set up on Mount Ebal — the text is quite elliptical in these lines. In any case, the final remark that "they hid them (the stones) on that very day" makes sense only if it refers to the stones of the altar. We may understand from a straightforward reading of mSot 7.5 that the altar built on Mount Ebal was a temporary one, meant to be dismantled after the Israelites's departure. In any case, this interpretation is found in ySot 7.5 (21d), which explicitly puts forward the idea that the stones which had been used for the altar were to be hidden. ${ }^{31}$

Therefore, the problem with the fact that the words of the Torah were written on the stones of the altar was that they were displayed for a very short time only. Hence the question in line 17: "How (could) the nations of the world see their judgement happen?" (meaning: if the altar was to be dismantled shortly afterward). In the Tosefta, R. Yehudah's answer is that God inspired the nations, which sent envoys to transcribe the Torah that was written on the stones (an answer reproduced in the corresponding passage of the Jerusalem Talmud). Here this tradition seems to be implicitly presupposed, unless we prefer to read the last sentence - "And they hid them (the stones) on that very day" - in a cynical way, as if the information was formally published, but in such a way as to make it impossible for the nations to become aware of it. Whatever the solution imagined by the rabbis, the main point here is that the apparently superfluous discussion about the nature of the stones on which the Torah was written is actually an important aspect of the underlying issue debated in these texts, the justification for the punishment of the nations, by demonstrating that the laws had been made known to them before they could be condemned. Indeed Hirshman has argued that the universalist perspective associated with the school of R. Ishmael was precisely the reason why idolatry among non-Jews, or the rejection of the precepts of the Torah more broadly, was sharply condemned in the writings associated with this school. ${ }^{32}$

In SifreDt, the section Dt $27.2-8$ is not commented on, as chapters 27 to 30 are wholly skipped over. ${ }^{33}$ It is therefore not possible to compare

31. See the discussion of ySot 7.5 (21d) below.

32. See Hirshman, Torah for the Entire World, 60, and the cautious criticism expressed by Menahem Kahana in "The Halakhic Midrashim," 52, n. 217.

33. For Natalie Dohrmann this omission did not happen by chance. According to her, in the Sifre "the key scenes of writing and deposit of the law are consistently and flagrantly ignored"; see Dohrmann, "Can 'Law' Be Private? The Mixed Message of Rabbinic Oral Law," in Public and Private in Ancient Mediterranean Law and Religion, ed. C. Ando and J. Rüpke (Berlin, 2015), 187-216, quotation 202. 
the interpretation of MekhiltaDt to that of the Sifre. However, the comparative analysis of other passages shows that there is indeed a difference of perspective between the two works concerning the possibility of communicating the Torah to non-Jews. In SifreDt \$343, for example, God wants to reveal the Torah to the nations, but the nations reject the offer and are thus not given the Torah - the only commandments that are made known to them are the commandments of Noah, which they prove unable to keep. Apart from these specific commandments, in Sifre the Torah is not actually communicated to the nations, either orally or in a written form. ${ }^{34}$ Conversely, in the MekhiltaDt and the texts examined above more broadly, at least according to some rabbis the whole Torah is made known to the nations, and in some cases it is even communicated to them in their own languages.

\section{I.4 Jerusalem Talmud, Sotab 7.5 (211)}

The last text we will examine comes from the Jerusalem Talmud. I leave aside the parallel passage from the Babylonian Talmud because it does not add much to the discussion.

[A] It was taught: [The words of the Torah] were written on the stones of the lodging place [avene ba-malon] [cf. Josh 4.3, 8]. [These are] the words of R. Yehudah.

[B] R. Yose says: It was on the stones of the altar that they were written.

[C] The one who says that the words of the Torah were written on the stones of the lodging [that is, in a stationary place, may well understand the following]: Every day the nations of the world send their scribes [notarim] and they transcribe [lit.: lift] the Torah, which was written in seventy languages.

[D] But the one who said that the words of the Torah were written on the stones of the altar [how can he explain that fact]? For is it not so that they were used only for a moment and then hidden away?

[E] [From his viewpoint,] it is [merely] another miracle. [That is to say,] the Holy One, blessed be he, gave insight into the heart of every

34. See SifreDt $\$ 343$ (ed. Finkelstein, 396): they did not even want to hear. Note that in a previous passage in the same section, God is said to have revealed the Torah in different languages, but to Israel alone ("When the Holy One blessed be he revealed himself to give the Torah to Israel, he did not speak to them in one language only, but in four languages"; §343, Finkelstein p. 395). See Fraade, From Tradition to Commentary: Torab and Its Interpretation in the Midrash Sifre to Deuteronomy (Albany, N.Y., 1991), 30-37. 
nation, so that they transcribed [lit.: lifted] the Torah, which was written in seventy languages.

$[F]$ In the view of him who said, they were written on the stones of the lodging, the following verse poses no problems: and plaster them with plaster [Dt 27.2]. But as to him who said that they were written on the stones of the altar, how does he explain this requirement, and plaster them with plaster?

[G] It was to be between one stone and the next.

[H] R. Samuel bar Nahmani in the name of R. Yohanan: And peoples will be as if burned to lime [Isa 33.12]. On account of plaster [that is, the writing on the plaster,] the verdict [or: death penalty; epophsin, from the Greek or from the Latin apophasid] for them was death [for they had access to the Torah and did not obey it].

[I] R. Abba bar Kahana in the name of R. Yohanan: [For the nation and kingdom that will not serve you shall perish;] those nations shall be utterly laid to waste [Isa 60.12]. From Horeb the verdict [epopbsin] concerning them was the death penalty. ${ }^{35}$

The Jerusalem Talmud first tries to determine on which stones the law was written. Whereas in the Tosefta, R. Yehudah expresses the view that the law was written on the stones of the altar, here another opinion is attributed to him: the words of the Torah were written on the stones of the lodging place where the Israelites spent the night. Exactly what is meant by the words avene ha-malon, "the stones of the lodging place," is unclear. The words could refer to the walls of an inn, or, according to a more literal rendering of the biblical text, to the stones which the Israelites took "to the place where they lodged [malon]," according to Josh 4.8. The Talmud would then be attributing to R. Yehudah the idea that the law was written on the stelae. R. Yose, who previously appeared in the MekhiltaDt in connection with a different issue, defends the opposite view, according to which the stones on which the law was written were the stones of the altar.

The idea that the law was written on the stones of the lodging place implies that they were meant to remain permanently, or at least for a while, as emphasized in section $C$, which states that the nations had time to send their scribes to transcribe the law, each scribe copying the transla-

35. Hebrew text according to MS Leiden, consulted on the website of the Academy of the Hebrew Language. The translation is mine but is based on Jacob Neusner, ed., The Jerusalem Talmud: A Translation and Commentary: Sotah (Peabody, Mass., 2010), 151-52. 
tion corresponding to his own language. The version in the Jerusalem Talmud makes clear that the scribes found the Torah already written in seventy languages (see section E), which corresponds to the opinion attributed to R. Shimeon in the Tosefta. On the other hand, the opinion attributed to R. Yose poses a problem, because the altar built on Mount Ebal was meant to be dismantled, and the stones hidden (as stated in section D: "they were used only for a moment and then hidden away"). The same solution as in the Tosefta is then provided (section E). In section $\mathrm{F}$ a further issue is raised: how is the commandment to plaster the stones with plaster (Dt 27.2) to be understood if the stones of the altar are meant, and if they had been inscribed with the words of the law? The answer is that the plaster was meant to be put between the stones rather than on the stones, thus leaving the letters visible (section $G$ ).

The word used for "plaster," sid in Hebrew, leads to a verbal analogy gezerab shavab - with the biblical verse "And peoples will be as if burned to lime [oid]" (Isa 33.12). An interpretation offered by R. Samuel bar Nahmani in the name of R. Yohanan suggests, through a "measure for measure" argument, that the nations will be punished in the sid (the lime) because of the sid (the plaster) - meaning: because of what was written on the plaster, the divine laws which they did not follow (section $\mathrm{H}$ ). As in the Tosefta, and to a lesser extent in the MekhiltaDt, we encounter the idea that because the divine laws were communicated to the nations by being written on the stones in seventy languages, the nations are judged and condemned, insofar as they have not lived according to the laws. Finally, in section I, this idea is further corroborated by wordplay between Horeb, another name for Sinai, the Mount of Revelation, and herev, the sword, meaning here the death penalty for the nations. The meaning remains that because the nations have refused the law revealed by God, they are doomed to destruction.

Before we turn to the evidence that sheds light on these rabbinic texts, attention should be paid to the Latin vocabulary used in the Tosefta and above all in the Jerusalem Talmud: first the notarin (from notarius), and then the epophsin, verdict or death penalty (from apophasis, which may be Greek but also Latin). ${ }^{36}$ In itself this vocabulary might not have been very significant, as Greek and Latin loanwords frequently appear in rabbinic

36. See Daniel Sperber, A Dictionary of Greek and Latin Legal Terms in Rabbinic Literature (Ramat Gan, 1984), 52-54, on apophasis. Other rabbinic texts that allude to the publication of imperial edicts use the word Jiatagma or prostagma; see Amram Tropper, "Roman Contexts in Jewish Texts: On 'Diatagma' and 'Prostagma' in Rabbinic Literature," JQR 95.2 (2005): 207-27. 
literature, but in my opinion it is the reasoning behind the tradition concerning the translation of the divine laws into seventy languages, which is very much at home in the Roman imperial world. ${ }^{37}$

\section{THE ROMAN CONTEXT OF THE TRADITIONS \\ CONCERNING THE TRANSLATION OF THE LAWS OF \\ THE TORAH INTO SEVENTY LANGUAGES}

In his book Imperial Ideology and Provincial Loyalty, Clifford Ando states that "Roman imperial culture ultimately both developed from and contributed to the institutionalization of a jural-political order based upon the consensual value commitments of both Romans and provincials," and that this consensus was based to a great extent on the work of the imperial administration and the energy the Roman authorities invested in the communication of their own norms and rules to the provincials. ${ }^{38}$ Natalie Dohrmann similarly emphasizes that "the message of imperial rule is folded in good measure with its medium - writing practices, media, circulation, public reading, storage, citation, and publication." ${ }^{39}$ Now, the publication of edicts, letters, or ordinances followed certain rules, such as the obligation to post the document publicly for at least thirty days. ${ }^{40}$ Numer-

37. This point was already mentioned in passing by Saul Liberman in Hellenism in Jewish Palestine, 201. See the discussion below. Interestingly, Dohrmann notes that "Deuteronomic legal performances share several elements with what we know of Roman legal communication, and these would have been apparent to a rabbinic reader" (“Can 'Law' Be Private?," 202). The texts presented above corroborate this statement, as they originally rely on a passage from Deuteronomy (combined with Joshua).

38. See Ando, Imperial Ideology and Provincial Loyalty in the Roman Empire (Berkeley, Calif., 2000), 79, and chapter 4 ("The Communicative Actions of the Roman Government"). As Ando writes, "Although the sheer abundance of Roman texts is striking, we must also marvel at the continuity of certain strands within Roman self-presentation throughout the period of Roman rule. Above all, the government at Rome always paraded its wish that its words should come to the attention of all its subjects" (81; see also 96). See also Rudolph Haensch, ed., Selbstdarstellung und Kommunikation: Die Veröffentlichung staatlicher Urkunden auf Stein und Bronze in der römischen Welt : Internationales Kolloquium an der Kommission für Alte Geschichte und Epigraphik in München (Munich, 2009).

39. Dohrmann, "Can 'Law' Be Private?” 188.

40. See Ando, Imperial Ideology, 99-100. Copies were also kept in the tabularia publica, where they could be consulted. On the practical problems raised by illiteracy, Ando writes: “The government's acknowledgment of the logistical difficulties faced by its subjects in fact extended to include the problem of literacy, in two ways: first, the government insisted that published materials should be legible; second, it probably required that all such texts be recited at least once at the time of their posting" (101). 
ous Roman sources explicitly testify to the need to publish the documents in a public place and in a way that makes them visible. ${ }^{41} \mathrm{~A}$ papyrus from Egypt, dated to the end of the second century C.E. or the beginning of the third and consisting of a letter addressed by the prefect of Egypt to the strategoi, thus specifies that a copy of the letter should be published "in a public place" (дemosia). ${ }^{42}$ Moreover, in both inscriptions and papyri, it is sometimes explicitly requested that the letters be clearly written: formulas such as saphesi kai eusemmois grammasi or eudēlois grammasin (in clear and distinct/visible letters) are common. ${ }^{43}$ Different media were used in order to communicate information or keep records, such as marble, bronze, whitened boards, papyrus, etc., but many ancient sources refer to whitened board or white stones, on which the letters would be more clearly visible. $^{44}$

Two sources are particularly interesting in this regard. The first dates from the Republican period, ca. 51/50 B.C.E., and consists of elaborate instructions given by a Roman governor to the conventus of the province of Asia, for which we have two epigraphical testimonies. I reproduce here the text from the copy found in the bouleuterion of Miletus:

For these reasons I have written to the koinon of the Greeks, to you, to Ephesus, Tralles, Alabanda, Mylasa, Smyrna, Pergamum, Sardis, and Adramyttium, in order that each of you might dispatch [copies of this letter] to the cities in your own judiciary district and see to it that the

41. See Ando, Imperial Ideology, 101-2.

42. $B G U$ IV 1086 col. 2, 1. 3. See Fritz F. Von Schwind, Zur Frage der Publikation im römischen Recht (Munich, 1940), 84, 86.

43. See Or. Gr. Inscr. II 665, l. 12 (49 CE); P. Oxy. VIII 1100, l. 3 (206 CE); Von Schwind, Zur Frage der Publikation, 83.

44. Most remarkable is a law dated to 100 B.C.E., regulating certain aspects of provincial administration, the Greek translation of which is preserved in two copies, one from Delphi and one from Cnidus. It prescribes that "the letters, engraved on a bronze tablet, or, if not, either on a marble slab or even on a whitened board, be openly published in the cities in a sanctuary or agora, in such a way that the people shall be able to read them properly from ground level" (Ando, Imperial Ideology, 82; the translation is Ando's, based on M. H. Crawford [ed.], Roman Statutes [London, 1996], 1:254, no. 12). According to Jean-Louis Ferrary, however, such prescriptions remained exceptional at that time; see Ferrary, "La gravure de documents publics de la Rome républicaine et ses motivations," in R. Haensch, ed., Selbstdarstellung und Kommunikation, 59-74, at 67-68. On the symbolic significance of the publication on bronze tablets, see Callie Williamson, "Monuments of Bronze: Roman Legal Documents on Bronze Tablets," Classical Antiquity 6.1 (1987): 160-83, who writes: "They were symbols of Rome and of Roman presence" (182). 
letter is engraved on a pilaster of white stone in the most conspicuous place, so that justice might be established for all time uniformly for all the province, and in order that all other cities and peoples might do the same thing among themselves, and that they might deposit [a copy of this letter] in the archives of the Nomophylakia and the Chrematisteria. Do not ask why I wrote in Greek, since it was my intention that nothing contrary to the interpretation of my letter could possibly be in your mind. 45

This document is a good example of the detailed instructions that were sent concerning the publication of official letters or edicts. Particularly noteworthy is the reference to the white stone (epi lithou leukou) on which the letter is to be engraved. In the rabbinic texts examined previously, the plastered stones would also have been whitened. Moreover, the fact that the pilaster must stand "in the most conspicuous place" implies that it should not be hidden, and this is precisely one of the issues debated by the rabbis in connection with the nature of the stones on which the Torah had to be written, at least in the Jerusalem Talmud: that is, the fact that the stones of the altar were meant to be hidden was problematic. More fundamentally, the legal implications of the publication of the letter are clearly stated: "so that justice might be established for all time uniformly for all the province." Similarly, the rabbinic texts dealing with the translation of the Torah are concerned with the justice of God's judgments. The statement that the publication is done "in order that all other cities and peoples might do the same thing among themselves" is also echoed in the rabbinic texts by the underlying idea that the scribes of the nations will bring the law back home and have it published there. The idea that a copy of the letter or the law will be deposited in the public archives (Jemmosia) is not explicitly formulated in the rabbinic texts pertaining to the translation of the Torah in seventy languages but is found in other rabbinic works. ${ }^{46}$

45. See R. K. Sherk, Roman Documents from the Greek East (Baltimore, Md., 1969), no. 52, 11. 42-57, p. 273-74. The translation follows Ando, Imperial Ideology, 83. See also L. Robert, "Le culte de Caligula à Milet et la province d'Asie," Hellenica 7 (1949): 227-28, and the remarks of Ferrary, "La gravure de documents publics," $70-71$.

46. On the word Jemosia in rabbinic texts, see below. Concerning archives, Fraade notes that in GenR 74.15 (ed. Theodor-Albeck, 872-73), it is said that in David's time, the Edomites and the Moabites produced stelae with verses from Deuteronomy (Dt 2.3 and 2.9) mentioning that the territories of these nations were not to be conquered, and thus that combat with them should be avoided (see Fraade, "The Torah Inscribed," n. 37). This archivistic practice recalls the practice of Greek cities or kingdoms that kept records of their treatises with 
Finally, there is the issue of language: the Roman magistrate had his letter written in or translated into Greek before sending it, to guarantee a better understanding by the recipients ${ }^{47}$ Similarly, in the rabbinic texts, at least according to R. Shimeon's view in the Tosefta, or R. Ishmael's view in the MekhiltaDt, or the opinion expressed in the Jerusalem Talmud, which states that the Torah was written on the stones in seventy languages (in accordance with R. Shimeon's view in the Tosefta), the law was translated in the languages of the nations in order for them to understand it.

Another relevant source quoted by Ando comes from the Digest and is attributed to the second-century jurist Ulpian:

By "public notice" we mean one written in clear letters (claris litteris), posted in such a way that it may be read properly from ground level, in front of an inn, for example, or in front of a place of business - not in a hidden place, but in the open (non in loco remoto, sed in evidenti). Should it be written in Greek, or in Latin? I think that depends on the location, lest someone be able to plead ignorance of the letters. Certainly, if someone should say that he didn't understand the letters or did not see what was posted, when many did read and the notice was publicly posted, then he will not be heard. ${ }^{48}$

As with the inscription from Miletus, several elements in this passage are of particular interest in order to contextualize the rabbinic texts concerning the translation of the Torah into seventy languages: the idea that the text should be written in clear letters, that one should be able to access it easily, that the document was sometimes published in front of an inn (!), ${ }^{49}$ and the idea that it should be written in a language that the people

Rome and of the privileges granted to them by Rome, often in the form of inscriptions on marble as well as bronze tablets.

47. In the Roman Empire we also find bilingual or even trilingual documents. See, for example, the letter of Hadrian concerning the reconstruction of a temple in Cyrene which had been burnt "in the Jewish riots," in Gaspare Oliverio, "Campagna di scavi a Cirene nell'estate 1927," Africa Italiana 2 (1928/29), 119 [AE 1929.9; SEG 9.168]. The Greek text was not necessarily an exact translation of the Latin, however; even when the content was the same, there were some differences, which may be understood as an effort to adapt the message to a specific audience. Augustus's Res Gestae is an interesting example of such a translation with adaptations.

48. Digest 14.3.11.3, trans. Ando, Imperial Ideology, 98.

49. This association works only in the case of the Jerusalem Talmud, however. 
understand. Moreover, the underlying reasoning is also significant: people can be sued on the basis of ordinances that are made public, and if enough people have knowledge of them, a person cannot argue that the information was not communicated properly. Which means that a contrario, if one had not been informed of the law first, one could not be judged and condemned.

Interestingly enough, Ando connects Ulpian's ruling to a rabbinic saying found in SongR:

R. Eleazar said: Although the Torah was revealed on Mt. Sinai, Israel was not punished for its transgression until it was promulgated to them in the Tent of Meeting. It was like an edict [Diatagma] that had been written and sealed and brought to the city, but in respect whereof the inhabitants of the city are not bound until it has been promulgated to them in a public place [démosia] of the city. ${ }^{50}$

The translation is that of Saul Lieberman in Hellenism in Jewish Palestine, where Lieberman comments as follows: "The Rabbi [meaning R. Eleazar] argued according to the legal practice of the Roman government. An edict had to be displayed demosia, in a public place; until then the people were not punishable for its transgression." ${ }^{51}$ Building on Lieberman's comment, Ando adds:

We should not fail to notice that R. Eleazar has drawn this analogy not simply with Roman practice, but with the reasoning behind it: it would not be fair to hold the inhabitants of a city liable for the contents of a law from the time when it was drafted; once, however, it has been properly promulgated, the burden of responsibility falls upon their shoulders. ${ }^{52}$

This remark is crucial and far-reaching, because this reasoning is central in rabbinic literature. The problem with Ando's demonstration, however, is that Song $\mathrm{R}$ is a late composition (sixth century?), even if this particular

50. SongR 2.13; Ando, Imperial Ideology, 98. Cf. LevR 1.10.

51. Lieberman, Hellenism in Jewish Palestine, 201. Both Lieberman and Ando rely on Fritz F. von Schwind, Zur Frage der Publikation, esp. 84, 86, 92. See also Tropper, "Roman Contexts in Jewish Texts," 213-16, who comments on LevR 1.10 .

52. See Ando, Imperial Ideology, 98. 
tradition may well go back to the tannaitic period. ${ }^{53} \mathrm{~A}$ parallel is found in LevR, but it is late as well.

A far better case can be made for the connection between this rabbinic reasoning and the early Roman imperial context if we look at Mekhilta de-Rabbi Ishmael (Bahodesh 1), a midrash that, in its final redaction, is dated to the third century C.E. ${ }^{54}$ In connection with Ex 19.2, "They (Israel) encamped in the wilderness," the midrash states that

They encamped in the wilderness (Ex 19.2). The Torah was given publicly (Heb. demos /cf. $\delta \tilde{\eta} \mu \mathrm{s}$ ), openly (Heb. parbesi'a /cf. $\pi \alpha \varrho \varrho \eta \sigma i \alpha)$, in a free place. For had the Torah been given in the Land of Israel, (the Israelites) would have said to the nations of the world, "You have no share in it." ${ }^{5}$ Therefore it was given in the wilderness publicly, openly, in a free place, [so that] everyone wishing to accept it, [may] come and accept it. ${ }^{56}$

The reasoning behind this text is similar to the one found in SongR, however, the context and the implications differ in the latter, which deals with the promulgation (not the revelation) of the law in the Tent of Meeting, within the Israelite camp, that is, in a strictly "national" context. In

53. According to Strack and Stemberger, Introduction to the Talmud and Midrash, 315, SongR dates from the middle of the sixth century C.E. but contains older material. R. Eleazar is probably to be identified with the third generation tanna R. Eleazar ben Shammua, one of the students of R. Akiva, but the attribution does not prove the antiquity of the saying attributed to him.

54. Although it is less directly connected to the issue of legal liability, another tannaitic text that sheds light on the reception of Roman administrative procedures in rabbinic literature is SifreDt $\$ 33$ on Dt 6.6 (ed. Finkelstein, 59), which states: "Which I command you this day (Dt 6.6): Let [these words] not be like an old edict (diatagma) to which no one pays any regard, but like a new edict to which everyone rushes to read" (trans. by Fraade in From Tradition to Commentary, 260, n. 7). This passage implies that the Torah is posted in public view, like a Roman edict. See also Tropper, "Roman Contexts in Jewish Texts," 217-18.

55. With a small correction to the edition of Horovitz-Rabin, 205, which has: "They have no share ..." MS Oxford 151 has: "You have no share ..." This is merely an issue of direct versus indirect speech.

56. Mekhilta, Babodesh 1 (ed. Horovitz-Rabin, 205). The translation is based on that of Jacob Z. Lauterbach, Mekbilta de-Rabbi Ishmael: A Critical Edition, Based on the Manuscripts and Early Editions with an English Translation, Introduction and Notes (2nd ed.; Philadelphia, 2004), 2:293-95, slightly modified. MS Oxford 151 omits the word demos in the first sentence, but it is present in the second. The idea that the Torah was given publicly (demos) and openly (parbesi ${ }^{\prime} a$ ) is found again in Balodesh 5 (ed. Horovitz-Rabin, 222). 
other words, in SongR, the issue of the communication of the law is an internal affair, not tied to the nations.

By contrast, the passage from the Mekhilta de-Rabbi Ishmael has been commented on for its universal conception of the Torah, because according to the midrash the Torah is made known to all peoples. In addition, Hirshman notes: "It is striking that the Mekilta not only advanced the claim that revelation had been intended for all peoples, but did so in a vocabulary that was the hallmark of Greco-Roman democracy." ${ }^{57}$ In my opinion the underlying issue, however, is not the political regime but rather the way laws were made public in the context of the Roman Empire. As we have seen, access to legal and administrative documents was a key issue, and this explains the insistence of the Mekhilta on the fact that the law was revealed "publicly, openly, in a free place." The fact that this place was a desert, a place where people are not expected to gather frequently, is irrelevant here, as is the fact that, in the tradition found in SongR, the Tent of Meeting was not a place to which regular Israelites had access. The rabbinic texts are not contemplating a historical, realistic scenario; rather, they deal with the principles underlying the publication process. As in Roman legal texts, the issue at stake in the Mekhilta is that people can only be judged - and condemned - if the laws have been properly communicated to them first. This is made explicit at the end of this section of the midrash:

R. Eliezer the son of R. Yose the Galilean used to say: Behold it says: He Jeclares bis word to Jacob... he bas not dealt so with any other nation [Ps 147.19-20]. But what had those wretched nations done that he did not want to give them the Torah? They do not know his ordinances [ibid.] they did not want to accept [them], as it is said: God comes from Teman ... and a brightness appears as the light ... before him goes the pestilence... be stands, and shakes the earth, he beholds, and makes the nations to tremble, etc. (Hab 3.3-6)..$^{58}$

The teaching is attributed to R. Eliezer, son of R. Yose, a tanna who lived during the second half of the second century C.E. On the basis of Ps 147.19-20, which states that God has not declared his word (Javar) to the nations, R. Eliezer expresses the view that God has not given the Torah

57. Hirshman, "Rabbinic Universalism in the Second and Third Centuries," 103.

58. Ed. Horovitz-Rabin, 206; trans. Lauterbach, Mekbilta Je-Rabbi Ishmael, 2:295, slightly modified. 
to the nations. This could be seen as contradicting the more universal view expressed a few lines before, according to which the Torah was given to anyone wishing to accept it (kol ba-rotseb le-kabel). There is no contradiction, however, because according to R. Eliezer, the point is precisely that the nations "were unwilling to accept them" (lo ratsu le-kabel), a piece of information he draws from Ps 147.20, "they have not known his ordinances." ${ }^{9}$ This teaching of R. Eliezer sheds light on the previous passage, the one expounding "They encamped in the wilderness." God indeed made it possible for the nations to receive the Torah, but they were not among those "wishing to accept it," and this is precisely what they are guilty of. This section of the Mekhilta de-Rabbi Ishmael makes clear that the nations cannot complain that God did not want to give them the Torah or claim that he dealt with them in a way that was unfair. The teaching of this passage is thus similar to the one found in the Tosefta, the Mekhilta Deuteronomy, or the Jerusalem Talmud, but it is associated with the Exodus narrative rather than with the commandments of Deuteronomy and the narrative found in Joshua.

Let us now return to the texts pertaining to the translation of the Torah into seventy languages. ${ }^{60}$ The rabbinic interpretation of the expression ba'er betev (very clearly) as a reference to the translation into the languages of the nations has, at least from the Tosefta onward, the same implications as the details concerning the publication of the Torah demos(ia) in other midrashim. Just as Ulpian answers the question "Should it be written in Greek, or in Latin?" by stating "I think that depends on the location, lest someone be able to plead ignorance of the letters," similarly the translation of the Torah (or part of it) into the languages of the nations implies that the nations will not be able to plead ignorance of the language of the Torah. ${ }^{61}$ Moreover, the rabbinic discussion over the nature of the stones on which the Torah was written directly

59. The passage from Habakkuk is quoted as further proof that the nations did not accept God's laws: he saw their disobedience and made them tremble. This same verse is quoted in b'AZ $2 b$, in a similar context: the nations appear before God and are condemned not only for not having accepted the Torah but also for not having even kept the seven commandments which the children of Noah had taken upon themselves.

60. As Lieberman noticed too; see Hellenism in Jewish Palestine, 201-2. But he did not analyze these texts in detail there, nor did he elaborate on the implications of these echoes between Roman and rabbinic traditions.

61. It seems that in the Digest, the issue is the alphabet rather than the language itself, but the former probably implies the latter. 
pertains to the possibility of the nations sending their scribes to copy the law. If the stones are not to remain permanently set up, as could be the case with the stones of the altar, then we encounter the problem that the scribes of the nations will not have the time to perform the transcription work. In that respect, the very next sentence in the passage from the Digest referred to previously is also significant. The text states that "it is necessary that the notice be permanently set up, otherwise if the contract was made at a time when there was no notice posted up, or it was hidden, the institorian action will lie." 62 The notion of being "permanently set up" may be taken literally or may refer to a period of thirty days, but what matters here is that the issue of the length of time during which the document was made public, and the question of whether the post was visible or hidden, was important in Roman legal texts.

It can hardly be coincidental that this issue lies at the core of the rabbinic discussion around the interpretation of Deuteronomy 27. It must be emphasized, however, that even though R. Yehudah (in the Tosefta) or R. Yose (in the Jerusalem Talmud) argue that the Torah was copied on the stones of the altar (with the implication, at least in the Talmud, that the stones would be set up only for a short time, which would contradict Roman norms of publication), they nevertheless maintain that the scribes of the nations had the opportunity to copy the law and bring it back home. As a consequence, in spite of the improper original conditions of promulgation, the nations are nevertheless legally bound by the law (or part of it) and will be punished accordingly if they fail to observe it. This is all the more true if the law was published in a public place, on the stelai, for an indefinite period of time. Yet R. Shimeon's opinion in the Tosefta may also be read as implying that the nations can still repent and be accepted by Israel.

\section{CONCLUSION}

Most rabbinic texts discussed in this essay, whether the ones concerning the translation of the Torah into seventy languages or the one found in the Mekhilta de-Rabbi Ishmael, reflect an awareness on the part of the rabbis of some of the rules followed by the imperial administration to communicate with the provincials, as well as of their legal implications. ${ }^{63}$ This is not the case of the passage in the Mishnah, however, which is

62. Digest 14.3.11.4.

63. On the rabbis' familiarity with "the contents, the publication, the reception, and the general perception of the Roman edict," see also Tropper, "Roman Contexts in Jewish Texts" (p. 227). 
mainly to be understood as an interpretation of Dt 28.1-8 combined with Josh 4. On the other hand, the awareness of the imperial context is particularly clear in the passage from the Jerusalem Talmud, which explicitly formulates the view that the Torah was translated into the languages of the nations and written on the stelae, in a public and accessible place and permanently, hence providing the scribes with the time necessary to perform the transcription. It must be emphasized again that it is not primarily the details of the procedures that are at stake here - there are of course numerous differences between the Roman sources and the rabbinic texts - but above all the very reasoning underlying the publication of legal documents in the Roman Empire: without properly communicating the law to the people, the latter cannot be considered legally liable. Hence the Roman evidence provides not just vague parallels but the very context that makes these rabbinic texts fully understandable and meaningful. ${ }^{64}$

By connecting the reasoning behind prescriptions for the publication of legal documents in the Roman Empire with the revelation of the Torah, what these rabbinic texts implicitly suggest is that the God of Israel is in the same position as the Roman emperor, that God makes his law known according to the same procedures as those followed in the Roman Empire, and that Israel is in charge of performing vis-à-vis the nations what the imperial administration did vis-à-vis the provincials, by publishing the text of the law in such a way as to communicate it properly to the nations, who can therefore not claim ignorance of it. ${ }^{65}$ In the language of postcolonial studies, we may call it mimicry and understand it as a way to

64. Dohrmann has shown that the rabbis were keenly aware of the challenge posed by Roman law and the Roman legal order and suggests that the development of the rabbinic halakhic discourse may to a large extent be seen as a response to such a challenge; see Natalie B. Dohrmann, "Law and Imperial Idioms: Rabbinic Legalism in a Roman World," in Jews, Christians and the Roman Empire: The Poetics of Power in Late Antiquity, ed. N. B. Dohrmann and A. Yoshiko Reed (Philadelphia, 2012), 63-78. In “Can 'Law' Be Private?" she argues that rabbinic orality may also be understood as a reaction into (or against) Roman legal culture and its pervasive written media.

65. In connection with ExodR 30.16, Amram Tropper similarly remarks: "Our midrash portrays God as the ultimate emperor and the mitzvot (i.e., the divine commandments) as his edicts" ("Roman Contexts in Jewish Texts," 213). Dohrmann also notes: "In the rabbinic theological imaginary, the rabbis function in relation to their god as do the legal experts in the inner circle of the deified princeps who translated and mediate his will" ("Can 'Law' Be Private?" 191). In the case examined here, however, it is Israel rather than the rabbis who function as an intermediary between God and the nations. 
ironically challenge or question the leading role of Rome. ${ }^{66}$ Interestingly enough, whereas the Roman administration mainly used two languages to communicate with the provincials, Latin and Greek, in some of the rabbinic texts examined above Israel is implicitly described as being able to produce a translation of the law in all the languages of the nations, a detail which might be interpreted as an ironic gesture of cultural superiority.

In a ground-breaking essay, Natalie Dohrmann has argued that "oral ideology [should] be seen as a rabbinic recusal from Roman legal life and the normative order proffered by the Empire," and in connection with the texts examined in this essay, she adds that "despite a powerful biblical tradition of the public inscription of God's laws, for the early rabbis, by contrast, law communicated in plaster or stone was treated as adulterated." ${ }^{67}$ However, the texts treated here concerning the translation into seventy languages, with their insistence on written publication, do not seem to me to convey a perception of the law written on the stones as "adulterated," even in the sense of being only partially transmitted, since several rabbis in these texts argue that the whole Torah was translated and communicated to the gentiles. Moreover, and even if the rabbis generally did not think about the biblical past in historical terms, the fact that the translation and transcription of the Torah was presented as a unique event occurring in the context of the conquest of the Land may be relevant here - the successful conquest of the Land by Israel makes the parallel between the publication of the Torah and the publication of Roman laws in the conquered provinces even more relevant.

Finally, I would like to emphasize that this analysis of the rabbinic traditions pertaining to the translation of the Torah into seventy languages challenges the interpretation of these texts as reflecting a universalistic conception of the Torah arising from a desire to reach out to the gentiles or from the conviction that the Torah was meant for all human beings and not for Israel alone. True, these texts speak about the commu-

66. In postcolonial studies, mimicry is identified as one of the strategies adopted by subalterns in order to resist imperial or colonial domination. See, for instance, Leo G. Perdue and Warren Carter, Israel and Empire: A Post-Colonial History of Israel and Early Judaism, ed. C. A. Baker (London, 2015). I fully concur that "the rabbinic legal project makes sense as a form of provincial shadowing of a dominant Roman legal culture” (Dohrmann, “Can 'Law' Be Private?” 188). In the traditions examined here, however, it is not the rabbinic legal project that is at stake but the rabbinic interpretation of a one-time event located in the biblical past.

67. Dohrmann, “Can 'Law' Be Private?” 204. 
nication of the content of the Torah to the nations. But they do so in an imperial context and as part of an ongoing inner reflection about imperial power. What these texts do first and foremost is to demonstrate the guilt of the nations and justify the latter's future punishment at the hand of God in a way that was culturally appropriate in the rabbis' cultural and political context. 